\title{
"Type 2a", the earliest Palaeolithic spear-thrower: a new Middle Magdalenian object from Isturitz (Pyrénées-Atlantiques, France) and its implications
}

"Type $2 a$ " the earliest type of Palaeolithic spearthrower: a new object in the Middle Magdalenian of Isturitz (Pyrénées-Atlantiques, France) and its implications

Pierre Cattelain et Jean-Marc Pétillon

\section{(2) OpenEdition}

\section{Journals}

Édition électronique

URL : http://journals.openedition.org/paleo/3025

DOI : $10.4000 /$ paleo.3025

ISSN : 2101-0420

Éditeur

SAMRA

\section{Édition imprimée}

Date de publication : 1 décembre 2015

Pagination : 17-32

ISSN : 1145-3370

\section{Référence électronique}

Pierre Cattelain et Jean-Marc Pétillon, «"Type 2a", the earliest Palaeolithic spear-thrower: a new Middle Magdalenian object from Isturitz (Pyrénées-Atlantiques, France) and its implications », PALEO [En ligne], 26 | 2015, mis en ligne le 26 avril 2016, consulté le 07 juillet 2020. URL : http:// journals.openedition.org/paleo/3025; DOI : https://doi.org/10.4000/paleo.3025

Ce document a été généré automatiquement le 7 juillet 2020

\section{c) (1)}

PALEO est mis à disposition selon les termes de la licence Creative Commons Attribution - Pas d'Utilisation Commerciale - Pas de Modification 4.0 International. 


\title{
“Type 2a", the earliest Palaeolithic spear-thrower: a new Middle Magdalenian object from Isturitz (Pyrénées-Atlantiques, France) and its implications
}

\author{
"Type $2 a$ " the earliest type of Palaeolithic spearthrower: a new object in the \\ Middle Magdalenian of Isturitz (Pyrénées-Atlantiques, France) and its \\ implications
}

Pierre Cattelain et Jean-Marc Pétillon

The authors extend warm thanks to Jacques Allain, Aline Averbouh, Malvina Baumann, Coralie Bay, Claire Bellier, Lucie Braem, Henriette Camps-Fabrer, Jean-Jacques Cleyet-Merle, Catherine Cretin, Henri Delporte, Dominique Buisson, Jean-Michel Geneste, Peggy Jacquement, Philippe Jugie, Marie-Sylvie Larguèze, Serge Maury, Christian Normand, Patrick Paillet, Marylène PatouMathis, Marie-Paule Pellan, Patrick Perrin, Stéphanie Renault, André Rigaud, Alain Roussot, Catherine Schwab, Ulrich Stodiek, Jean-François Tournepiche and Carole Vercoutère for access to collections, shared data and advice. Thanks also to Malvina Baumann for the drawing in figure 2, Claire Bellier for the other drawings and Kimberley Watt for the English translation. This research was supported by the Magdatis project (ANR 2011 BSH3 0005).

The spear-thrower presented here was discovered in 1932 during the excavations led by R. and S. de Saint-Périer in the famous cave of Isturitz. But the fragmentation of the object and its unpredictable museographic fate delayed its identification by nearly three-quarters of a century... This piece is made up of two fragments currently curated in different museums. Since 1981, the mesio-proximal part has been conserved in the National Archaeology Museum in Saint-Germain-en-Laye, where it was initially kept in a box containing antler spear tip fragments, then separated from the other pieces by D. Buisson in 1994, identified as a possible spear-thrower fragment and published as such 
by U. Stodiek (1993 - p. 220, fig. $132 \mathrm{n}^{\circ} 6$ and pl. $42 \mathrm{n}^{\circ} 1$ ), then by P. Cattelain and U. Stodiek (1996 - p. 79, fig. 2, $\left.\mathrm{n}^{\circ} 10\right)$. The distal part bearing the hook has been kept in the municipal museum of Saint-Gaudens since 1967 and was published by M. Allard and M. Jarry as a fragment of an indeterminate notched piece (Allard and Jarry 1993 - p. 59, fig. $\left.5, \mathrm{n}^{\circ} 31\right)$.

2 In December 2005, after a visit to Saint-Gaudens Museum as part of a joint project on Isturitz spear-thrower technology, one of us (JMP) identified this second fragment as a possible part of the first. The connection between the two parts was first of all simply graphic - based on the published drawings (fig. 1) -, and was physically substantiated in April 2008 when the distal fragment was transported to MAN for this purpose (Cattelain, in press).

\section{Description}

The two fragments come from the Great Hall of Isturitz Cave, more specifically from layer II attributed to the Middle Magdalenian (Saint-Périer 1936; Pétillon 2004). The reconstituted object is $85 \mathrm{~mm}$ long (fig. 2) with a mesial width of $6.8 \mathrm{~mm}$ and a mesial thickness of $12.8 \mathrm{~mm}$. The proximal part is well preserved, but the end is missing. The distal end, beyond the hook, presents indeterminate splintering. The break between the two fragments is post-depositional and does not result from an accident related to fabrication or use.

Figure 1 - Type 2a spear-thrower, Isturitz, layer II: the two originally published elements. 1. Fragment from the Saint- Gaudens museum (Allard \& Jarry 1993 - fig. 5, $n^{\circ} 31$ ); Fragment from the Musée d'archéologie nationale (Ist II 1932, drawing C. Bellier 1995).
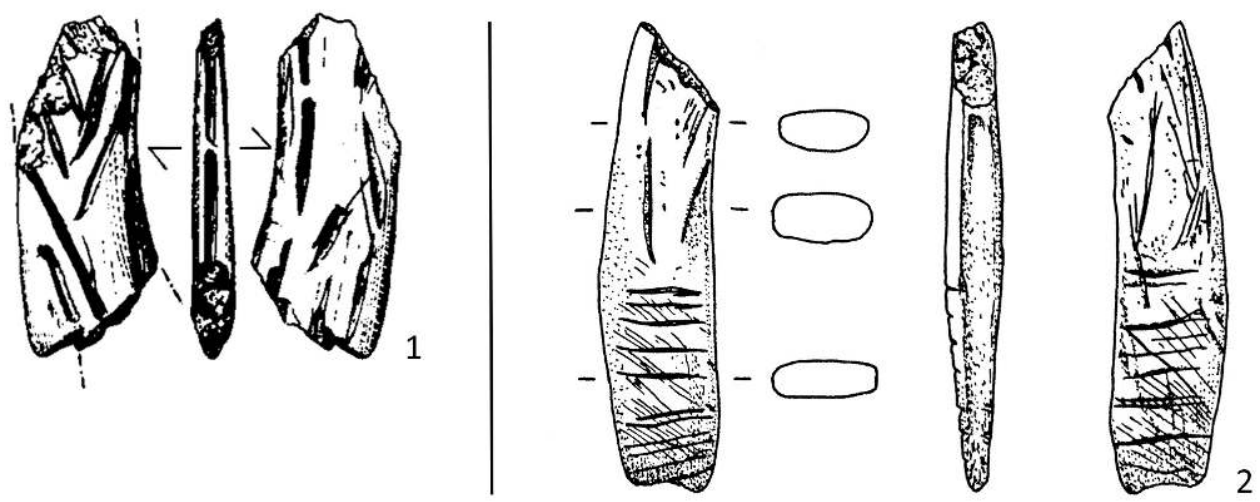
Figure 2 - Type 2a spear-thrower, Isturitz, layer II: the two reassembled fragments, photo J.-M. Pétillon \& P. Cattelain 2009-2015, drawing M. Baumann 2015.
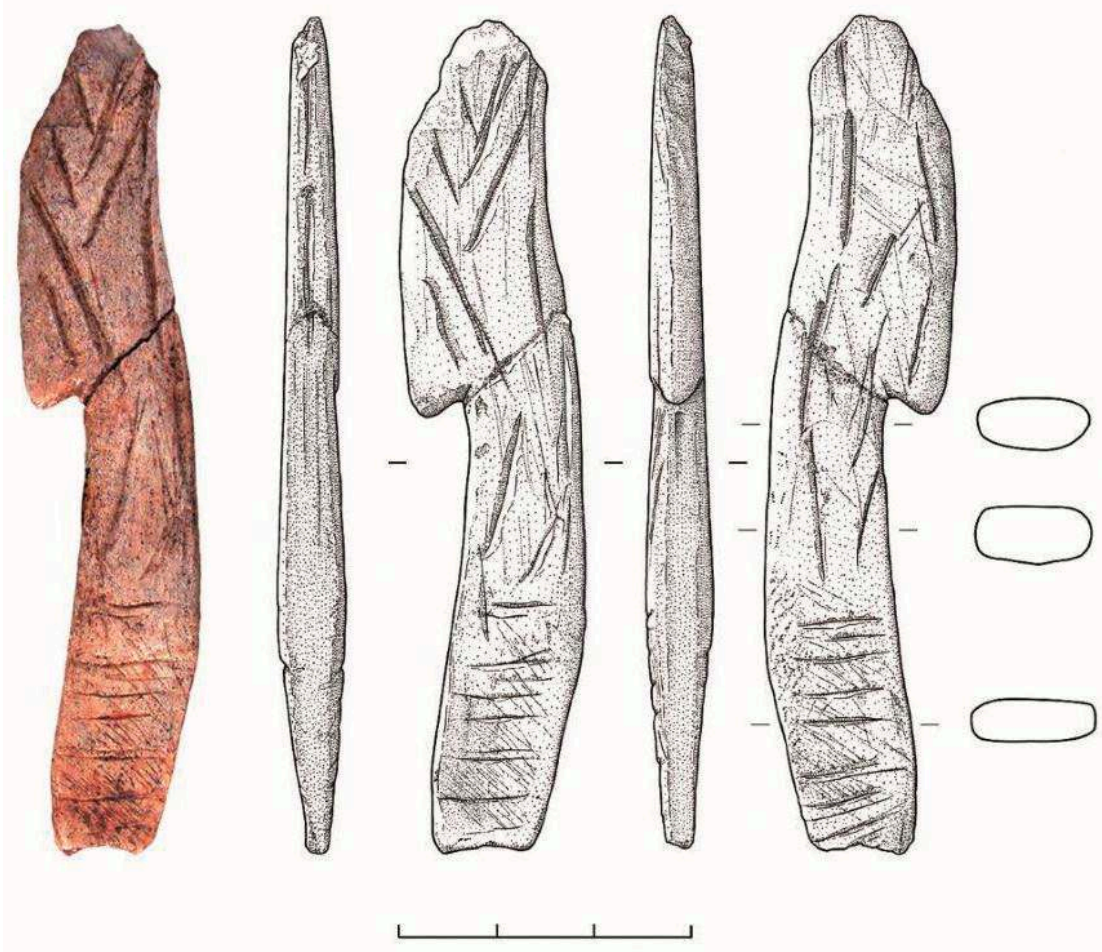

This piece is in reindeer antler and is entirely made of compact bone tissue. The dimensions show that it was made on a rod at least $18 \mathrm{~mm}$ wide, with compact tissue at least $7 \mathrm{~mm}$ thick. A blank of this calibre could only have been extracted from an adult male reindeer antler, probably from beam A or from the medial or lateral surface of the bez tine.

Near the break of the mesio-proximal fragment, a very slight protuberance on the upper surface pointed to the beginning of a hook, even before the two fragments were connected. This observation is confirmed by the refit, which shows a hook with an open acute angle, $5.9 \mathrm{~mm}$ long, described as a "stem" by M. Allard and M. Jarry (1993 - p. 59). This hook was probably made by scraping and incision from the upper surface, and does not seem to have involved grooving - the lower surface presents fine transverse striations, traces of scraping or incision, while the lateral surfaces of the object do not bear traces of oblique grooves observable on spear-throwers made by bilateral grooving (see below).

6 The lower surface of the piece shows three longitudinal fusiform incisions. The upper surface was levelled by scraping, as shown by the presence of a cluster of slightly oblique, fine longitudinal striations. Both of the lateral surfaces of the mesio-distal part bear quite deep incisions, which seem to outline a non-figurative decoration. The proximal part is $26.3 \mathrm{~mm}$ long with a double bevel and bears 11 transverse incisions on each surface. They overlap the oblique scraping striations resulting from fabrication.

7 These incisions were clearly designed to improve the adherence of the sticky substance used for hafting, as observed by U. Stodiek (1992 - p. 325) and experimentally shown by J. Allain and A. Rigaud (1989) for points with bevelled bases with similar incisions. 


\section{Typology and comparisons}

8 This spear-thrower is a type 2 piece, "a male spear-thrower, at times with engraved ornamentation that does not modify the overall baguette shape" (Cattelain1988). However, one of us showed the heterogeneity of this type, which comprises at least two different groups (Cattelain 2004, 2005, 2014).

The first group (type 2a) currently includes 15 pieces from seven sites (tab. 1). These spear-throwers are characterized by five criteria (fig. 3):

- they are short: from 6 to $9 \mathrm{~cm}$ for the whole or nearly whole pieces (with one exception, see below);

- the proximal end always bears a single bevel (with two exceptions, see below);

- they are generally made on a single reindeer antler rod (flat blank) and not on a segment (thicker blank);

- the hook generally forms an acute and open angle, with a triangular section, on account of a specific shaping process: involving scraping and incision from the upper surface, and not bifacial grooving (fig. 4, nos 1 and 2);

- in many cases, there is no decoration; when decoration is present, it is never figurative and is limited to short and straight incisions arranged in simple patterns (series of longitudinal or transverse incisions, Saint-Andrew's cross).

10 The fourth and fifth defining criteria (hook shape, absence of figurative decoration) are applicable to all the pieces, and the first two (length and type of hafting) are almost systematic. Only three specific cases must be mentioned: one of the pieces from Placard Cave is incomplete but clearly longer than the others, measuring nearly $15 \mathrm{~cm}$ (fig. 3, no 1); on two other pieces, the proximal part, which is generally a simple bevel, is slightly different - a simple bevel with perforation for one of the pieces from Roc de Marcamps (fig. 6, no 1), and a double bevel for the piece from Isturitz.

Only the third criterion presents higher variability (choice of blank), as although most of the pieces are made on rods, at least five - the longest specimen from Placard (fig. 3, no 1), the piece from Combe-Saunière I, the two from La Garenne (fig. 6, no 3) and at least one other piece from Placard (Cattelain 2014) - are made on thicker pieces. However, the existence of a high proportion of pieces on rods is in itself a strong differentiating criterion.

These 15 pieces thus present sufficiently marked similarities to create a specific group, which we suggest calling "type 2a" or "Placard type" spear-throwers, after the name of the site with most of these objects to date. It is also noteworthy that these objects are never found at sites in association with other types of spear-throwers, apart from the Isturitz piece. We will come back to this point below.

The second group of spear-throwers - which we will call "type $2 b$ " - is not very abundant (fig. 5). It generally contains long pieces, often with a perforated base, and always made on thick blanks, i.e. on sections of reindeer antler, with the spongy tissue at the centre of the piece. The objects from this group are most often associated with type 3 and 4 spear-throwers (with sculpted decoration), which are made on the same type of (thick) blank with the same hook shaping technique: bilateral grooving from the right and left sides, defining a conical-shaped hook (fig. 4, nos 3 and 4). 
Table 1 - List of "type 2a" spear-throwers. La Garenne: unpublished data. Le Placard: Chauvet 1910; Breuil 1937; Cattelain 2004, 2014. Combe-Saunière I: Cattelain 1989. Le Roc de Marcamps:

Roussot et Ferrier 1970; Langlais et al. submitted a. El Mirón: González Morales et Straus 2009. El Castillo: Cabrera 1984.

\begin{tabular}{|c|c|c|c|c|c|c|c|}
\hline \multicolumn{8}{|c|}{ PROPULSEURS DE TYPE 2a ou TYPE PLACARD } \\
\hline PAYS & DEPARTEMENT & LOCAUTE & \begin{tabular}{l|l} 
GISEMENT \\
\end{tabular} & \begin{tabular}{|c|}
$N^{*} \ln v$. \\
\end{tabular} & ETAT CONS. & BASE & ATRRIBUTION CULTURELLE \\
\hline ESPAGNE & CANTABRIA & PUENTE VIESGO & ELCASTILOO & 5137-32 & Presque complet & 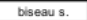 & Magdaténien intentieur cantabrique \\
\hline & CANTABRIA & RAMALES DE LA VICTORAA & ELMIRÓN & & Complet & biseau s. & Magdaléenien inférieur canta brique \\
\hline FRANCE & CHARENTE & VILHONNEUR & $\begin{array}{ll}\text { LE PLACARD } \\
\end{array}$ & MAN 55 187a & Complet & biseau s. & Magdalénien moyen \\
\hline & & & & MAN 551870 & hoomplet & $?$ & Magdalénien moyen \\
\hline & & & & Breull 1912, fig. $24 \mathrm{n}^{2} 6$ & noomplet & $?$ & Magdalénien moyen \\
\hline & & & & Chauvet $1910, \mathrm{fg} .71$ & hoomplet & $?$ & Magdalénien moyen \\
\hline & & & & Angoulême & Complet & biseau s. & Magdalénien moyen \\
\hline & & & & IPH, 1919-1, 20-220 & hoomplet & $?$ & Magdalénien moyen \\
\hline & INDRE & SAINTMARCEL & LA GARENNE & Musée đ'Argentomagus, 999-10-1292 SM-L1-85 & hoomplet & $?$ & Magd. moyen à navettes \\
\hline & & & & 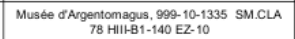 & noomplet & ? & Magd. moyen à navettes \\
\hline & DORDOGNE & SARLLAC-SUR-LISLE & COMBE SAUNIËRE 1 & $\mathrm{~K} 16 \mathrm{C} 216+49$ & hoomplet & $?$ & Solutéen superieur \\
\hline & GIRONDE & PRIGNAC-ET-MARCAMPS & ROC DE MARCAMPS & M.AQ. 7019 - coll. Maziaud & Complet & bise au s. pert. & Magd. moyen à naveties \\
\hline & & & & M. Aq. nL. - coll. Maziaud & Presque complet & biseau s. & Magd. moyen à navetles \\
\hline & & & & M. Aq. n.i. - coll. Ferrier & hoomplet & $?$ & Magd. moyenà naveties \\
\hline & PYRÉNEESATLANTIQUES & SAINT-MARTIN-DARBEROUE & ISTURITZ & MAN Ist.|l 1932 & Presque complet & bisean d. & Magdalénien moyen \\
\hline & & & & & & & 15 \\
\hline
\end{tabular}

Figure 3 - Type 2a spear-throwers. Le Placard, MAN, 55187b, MAN 55187a, Angoulême Museum, n.i., drawings C. Bellier 2003, 1989, 2004.

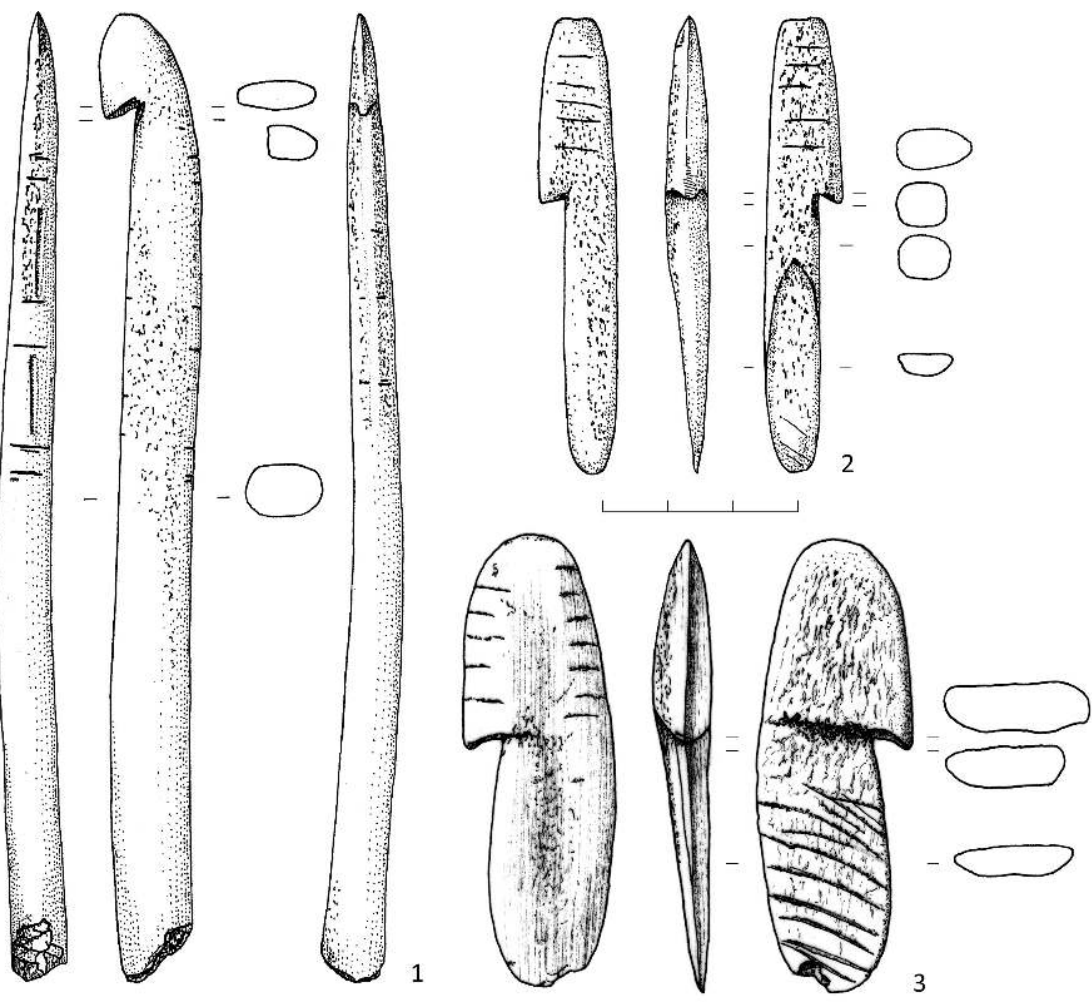


Figure 4 - Detail of the shaping of the hook on type 2a spear-throwers (1-2) and type $2 b$ spearthrowers (3-4; the "R" arrow indicates grooving). 1-2. Le Placard, MAN 55187a, MAN 55187b. 3-4. Le Mas d'Azil, MAN 47295, MAN 48000. Pictures J.-M. P.
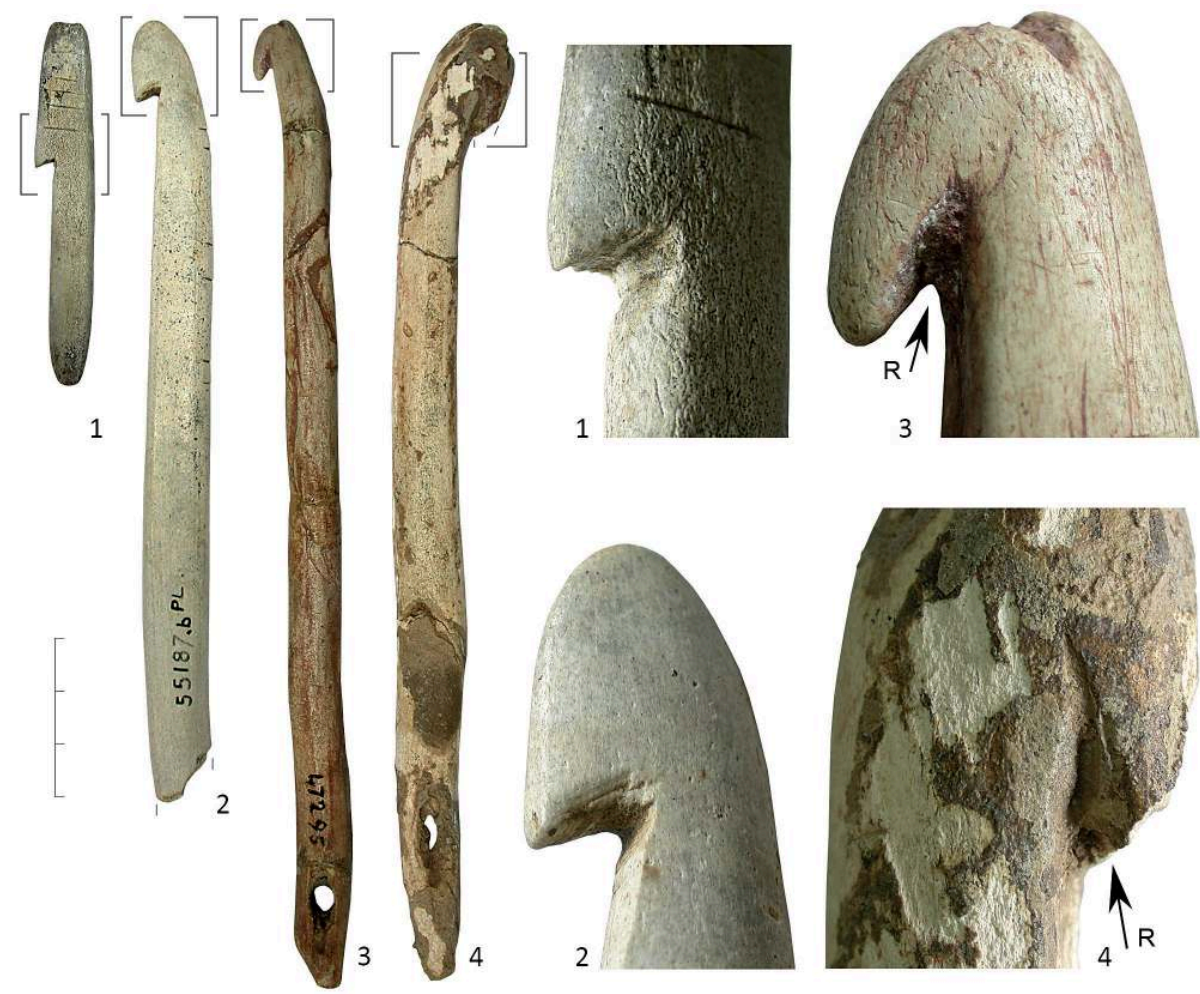

\section{Geographic distribution of the type $2 a$ spear-throwers}

The identification of a type 2a spear-thrower at Isturitz, as well as the discovery of a spear-thrower from the same category at El Mirón (González Morales and Straus 2009), provides new elements for analyzing the geographic distribution of this type of piece. Based on the currently known objects, and without prejudice to new discoveries, the $2 \mathrm{a}$ type spear-throwers present a distribution centred on the Charente and nearby regions (southern Vienne, northern Dordogne, northern Gironde), with an extension into Basque country and the Cantabrian region (fig. 7).

This map raises two questions. First of all, this distribution contrasts sharply with that of all the other types of spear-throwers. The type 2a pieces are often absent from the Vézère and Aveyron valleys, the French Pyrenees (apart from Isturitz) and the Aude, which yielded most of the type 1 spear-throwers (androgynous), 2b, 3 and 4 (with sculpted decoration: illustrations and distribution maps, not illustrated here, can be consulted in Cattelain 1988, 2005).

Then, as stated by M.R. González Morales and L.G. Straus (2009 - p. 276), the presence of similar pieces in two separate regions - on one hand charente and the bordering zones, and on the other Cantabria and Basque country - points to the existence of long distance contacts between these zones. 


\section{Chronocultural distribution of the type 2a spear- throwers, apart from Isturitz}

17 The spear-throwers from Placard (fig. 3) are from early excavations, with no stratigraphic indications. The absence of reliable chronostratigraphic data for the objects discovered during these excavations is particularly problematic in that this site has yielded the highest number of type 2a spear-throwers. However, it is on the basis of this material that H. Breuil defined the Magdalenian I to III, in 1912, and attributed three of these spear-throwers discovered by A. de Maret to the Magdalenian III (Breuil 1937 - fig. 24), based on traces of sediment on the objects.

The spear-thrower from Combe-Saunière I was discovered at the top of the Solutrean sequence (Geneste and Plisson 1990 - p. 294), in layer IV attributed to the Upper Solutrean (Geneste and Plisson 1986; Cattelain 1989). However, this spear-thrower is too fragmentary to confidently attribute it to a type $2 \mathrm{a}$. In addition, the 10 currently published 14C AMS dates for layer IV are disparate (tab. 2, fig. 8): four of them are between $14890 \pm 200 \mathrm{BP}$ and $15200 \pm 200 \mathrm{BP}$, and the excavators note the presence of Magdalenian elements at the top of layer IV (Geneste and Plisson 1986 - p. 12). Due to these uncertainties, we provisionally excluded the Combe-Saunière I spear-thrower from the discussion on the chronocultural distribution of type 2a.

One of the two spear-throwers discovered at Abri Blanchard from La Garenne comes from level $\mathrm{B} 5$, attributed to the Magdalenian à navettes (fig. $6, \mathrm{n}^{\circ} 3$ ). Unfortunately, the second one was found during illicit excavations. The three available $14 \mathrm{C}$ AMS dates for levels B4, B5 and B6 are respectively: $15010 \pm 90 \mathrm{BP}, 15050 \pm 90 \mathrm{BP}$ and $15290 \pm 90 \mathrm{BP}$ (Despriée, Tymula, Renault-Miskovsky 2009).

At Roc de Marcamps, two spear-throwers are from the Maziaud collection (1933-1942 excavations - fig. 6, nos 1 and 2), and the third is from the Ferrier collection. They come from one of the three identified Magdalenian levels (layers 5, 6 and 7 of the excavations conducted from 1931 to 1933 by the Société linnéenne de Bordeaux: Lenoir 1983, p. 332), but do not bear any more specific stratigraphic indications (Roussot and Ferrier 1970, p. 294). H. Breuil (1937 - p. 46) attributes the material to the Magdalenian III. A. Roussot and J. Ferrier (1970, p. 295) note the presence of the Upper, or even the Final Magdalenian, at the top of the sequence, but acknowledge the presence of a Magdalenian III with navettes at its base. Le Roc de Marcamps is also among the main sites of the Magdalenian with navettes in the inventory of Allain et al. (1985). Excavations conducted by M. Lenoir between 1978 and 1988 beside the Maziaud trench (locus 1) and in a second sector located at some distance from the early excavations (locus 2) led to a better definition of the stratigraphy, by distinguishing several layers attributed to the Middle Magdalenian: in locus 1, C2, C3 and top of C4; in locus 2, C2 and C3 (Lenoir 1983, p. 367; Lenoir 1993a, 1993b). The material from locus 2 was recently revised (Kuntz et al. 2015), and 10 AMS $14 \mathrm{C}$ ages were obtained on faunal remains from both loci and on characteristic bone industry from early excavations (navette, double bevelled point and perforated baton with phallic decoration, all from the Maziaud collection: Langlais, Pétillon, Sécher, submitted; Barshay-Szmidt et al., submitted). All of these results confirm the attribution of the Magdalenian occupations of Roc de Marcamps to an early phase of the Middle Magdalenian. Dates conducted on the bone industry range from $15630 \pm 70 \mathrm{BP}$ to $15340 \pm 70 \mathrm{BP}$ (tab. 2, fig. 8). 
Figure 5 - Type $2 b$ spear-throwers. 1. Le Mas d'Azil, MAN 47295, drawing C. Bellier 1984; 2. Le Mas d'Azil MAN 48000, drawing C. Bellier 1982.

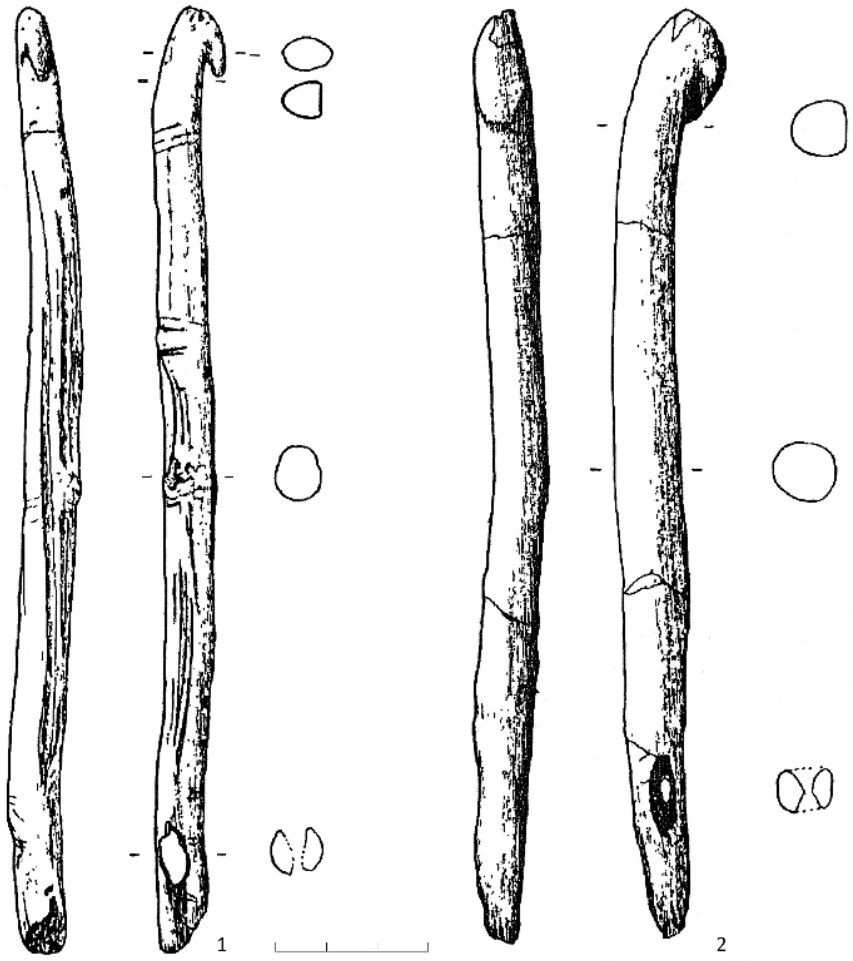

Figure 6 - Type 2a spear-throwers. 1-2. Le Roc-de-Marcamps, Musée d'Aquitaine, Bordeaux, M.Aq. 7019 and n.i., drawings C. Bellier 2004; 3. La Garenne, Argentomagus Museum 999-10-1292 SM.L1-B5, drawings C. Bellier 2004; 4. El Mirón (González Morales \& Strauss, 2009, fig. 6 to 8).

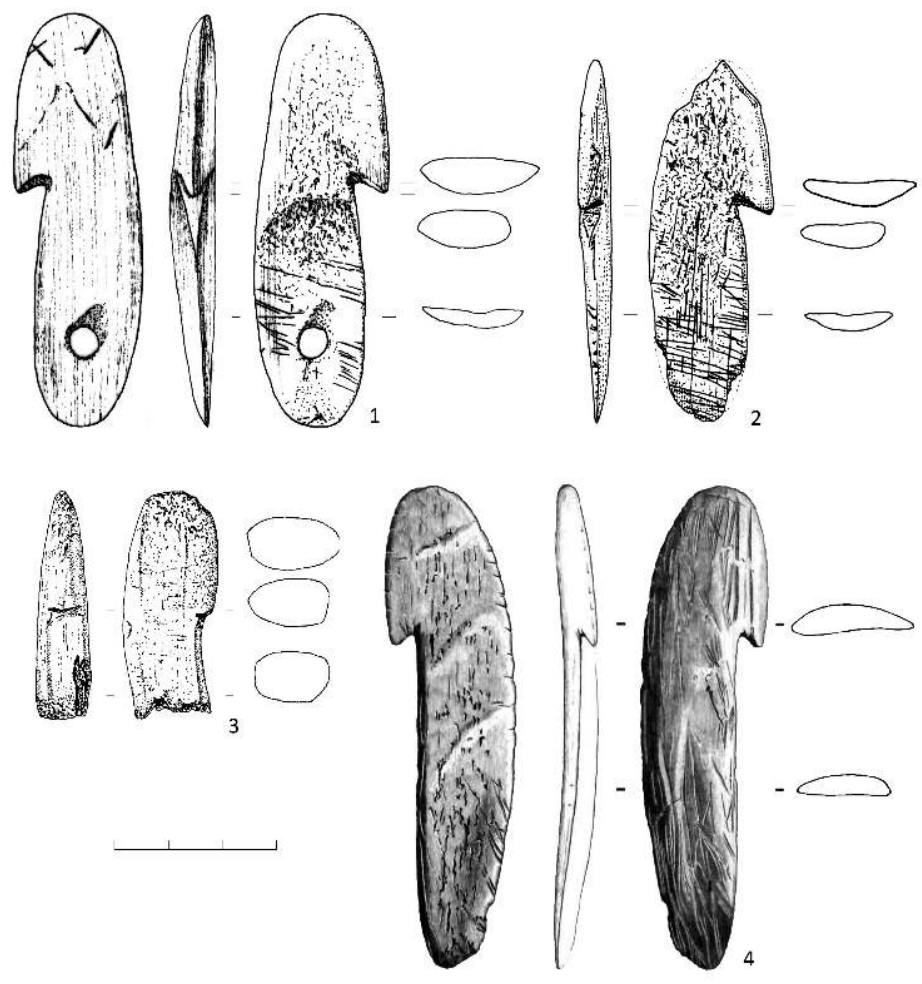


Figure 7 - Geographic distribution of type 2a spear-throwers. 1: El Castillo. 2: El Mirón. 3: Isturitz. 4: Le Roc de Marcamps. 5: Combe-Saunière I. 6: Le Placard. 7: La Garenne. The size of the dots is proportional to the number of specimens.

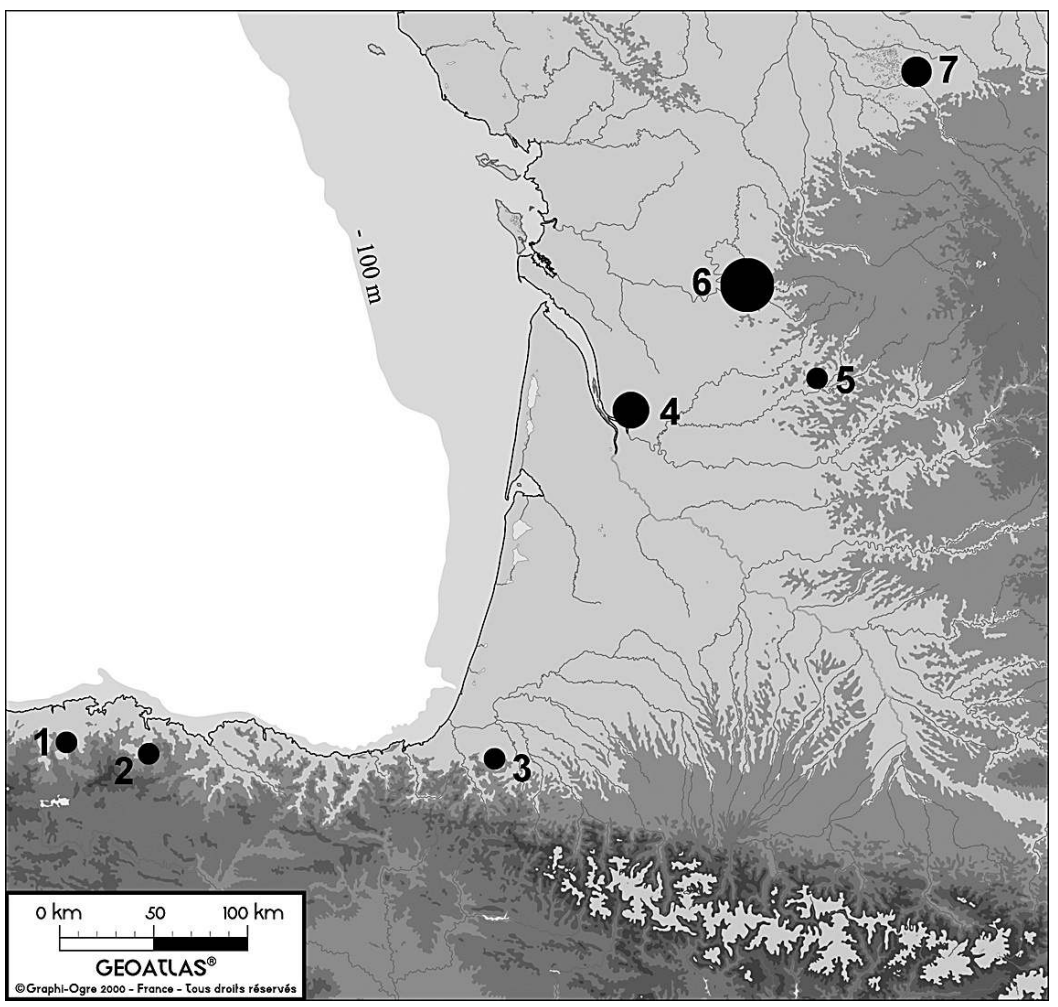

21 The El Mirón spear-thower (fig. 6, no 4), along with one of the objects from La Garenne, comes from the best documented archaeostratigraphic context. It was discovered in June 2007, in the "cabin" sector of the cave, at the base of level 17. This level is attributed to the Cantabrian Lower Magdalenian ("the Cantabrian Lower (not Initial) Magdalenian": González Morales and Straus 2009, p. 273) - partly because of the presence of a scapula with an engraved doe's head in the characteristic style of this period. The five $14 \mathrm{C}$ dates for this level - including two AMS dates and three classical dates - range from $15370 \pm 80$ BP to $15700 \pm 190$ BP (Straus and González Morales 2003, 2007; Straus et al. 2015). 
Table 2 - List of $14 \mathrm{C}$ dates stratigraphically associated with type 2a spear-throwers. Only AMS dates have been taken into account. La Garenne: Despriée et al., 2009. Combe-Saunière I: Geneste and Plisson, 1986. Le Roc de Marcamps: Langlais, Pétillon, Sécher, submitted; Barshay-Szmidt et al., submitted. Isturitz : Szmidt et al. 2009; Henry-Gambier et al. 2013; Langlais, Pétillon, Sécher, submitted; Barshay-Szmidt et al. submitted. El Mirón: González Morales and Straus 2009; Straus and González Morales 2007; Straus et al. 2015. El Castillo: Barandíarán 1988.

\begin{tabular}{|c|c|c|c|c|c|}
\hline Site & Couche & Échantillon & Âge BP & $N^{\circ}$ labo & Nom sur fig. 6 \\
\hline La Garenne & B4 & os (Equus) & $15010 \pm 90$ & ETH 28494 & GarB4 \\
\hline La Garenne & B5 & os (Bos) & $15050 \pm 90$ & ETH 28493 & GarB5 \\
\hline La Garenne & B6 & os (Rangifer) & $15290 \pm 90$ & ETH 28492 & GarB6 \\
\hline Combe-Saunière I & $\mathrm{IVb}$ & os & $14890 \pm 200$ & OxA 755 & CS4b_os1 \\
\hline Combe-Saunière I & $\mathrm{IVb}$ & os & $15120 \pm 200$ & OxA 756 & CS4b_os2 \\
\hline Combe-Saunière I & $\mathrm{IVb}$ & os & $15190 \pm 200$ & OxA 751 & CS4b_os3 \\
\hline Combe-Saunière I & $\mathrm{IVb}$ & os & $15200 \pm 200$ & OxA 754 & CS4b_os4 \\
\hline Combe-Saunière I & IV sommet & os (Aves) & $16300 \pm 220$ & OxA 485 & CS4sommet \\
\hline Combe-Saunière I & IVa & os & $17700 \pm 290$ & OxA 488 & CS4a \\
\hline Combe-Saunière I & $\mathrm{IVb}$ & os & $18860 \pm 320$ & OxA 757 & CS4b_os5 \\
\hline Combe-Saunière I & IV & os & $19450 \pm 330$ & OxA 489 & CS4 \\
\hline Combe-Saunière I & $\mathrm{IVb}$ & os & $19490 \pm 350$ & OxA 752 & CS4b_os6 \\
\hline Combe-Saunière I & $\mathrm{IVb}$ & os & $19630 \pm 320$ & OxA 753 & CS4b_os7 \\
\hline Roc de Marcamps & Maziaud & BdC (navette) & $15340 \pm 70$ & OxA X 2482-19 & RdM_Maz_nav \\
\hline Roc de Marcamps & Maziaud & BdC (b. percé) & $15380 \pm 70$ & OxA 27394 & RdM_Maz_bp \\
\hline Roc de Marcamps & Maziaud & BdC (pte bis. dble) & $15630 \pm 70$ & OxA 26665 & RdM_Maz_pbd \\
\hline \begin{tabular}{|l|} 
Isturitz \\
\end{tabular} & II & BdC (propulseur) & $12245 \pm 60$ & OxA 19837 & Istll_prop \\
\hline Isturitz & II & os (Pyrrhocorax) & $12455 \pm 55$ & OXA 28080 & Istll_Pyrrho1 \\
\hline Isturitz & II & os (Pyrrhocorax) & $12460 \pm 50$ & OxA 29933 & Istll_Pyrrho2 \\
\hline Isturitz & II & os (Homo) & $13035 \pm 45$ & GrA 45329 & Istll_Homo1 \\
\hline Isturitz & II & BdC (bag. demi-r.) & $13605 \pm 65$ & OxA 19838 & Istll_bagdemir \\
\hline Isturitz & II & BdC (double-pte) & $14605 \pm 70$ & OxA 28084 & Istll_doublepte \\
\hline Isturitz & II & os (Homo) & $14750 \pm 50$ & GrA 45328 & Istll_Homo2 \\
\hline Isturitz & II & BdC (pte Lussac-A.) & $15020 \pm 70$ & OxA 28083 & Istll_PLA1 \\
\hline \begin{tabular}{|l|} 
Isturitz \\
\end{tabular} & II & BdC (pte Lussac-A.) & $15130 \pm 110$ & OxA 19836 & Istll_PLA2 \\
\hline El Mirón & 17 & charbon & $15370 \pm 80$ & GX 32654 & Mir17_charb \\
\hline El Mirón & 17 & os & $15610 \pm 90$ & OxA 22093 & Mir17_os \\
\hline El Castillo & 8 & BdC (bag. décorée) & $16850 \pm 220$ & OxA 971 & Cast8 \\
\hline
\end{tabular}

The El Castillo spear-thrower (Cabrera 1984, p. 342) comes from the "Magdalenian beta" layer, excavated by H. Obermaier in 1911-1912 and referred to as "level 8" by V. Cabrera (1984 - p. 102). According to the excavation notebooks and publications by $\mathrm{H}$. Obermaier, this layer is 145 to $200 \mathrm{~cm}$ thick and is made up of several deposits of different colours and textures. The material from these deposits is mostly attributed to the Cantabrian Magdalenian III, or the Lower Magdalenian, but this layer undoubtedly comprised internal subdivisions which can now no longer be distinguished (Cabrera 1984 - p. 355). A piece of bone industry from level 8 was dated to $16850 \pm 220 \mathrm{BP}$, but I. Barandíarán points out that this date is unusually old for this type of archaeological context (Barandíarán 1988 - p. 73) and the question of its association with the spearthrower cannot be resolved.

The available information from the different sites is thus very disparate in terms of accuracy and reliability. In the current state of knowledge, apart from the specimen from Combe-Saunière I, the classical cultural attribution of these pieces includes the "Cantabrian Lower Magdalenian", the "Magdalenian à navettes" and "Magdalenian III" (the pieces from Placard could be related to one of the two latter attributions). 
Figure 8 - Calibration of $14 \mathrm{C}$ dates stratigraphically associated with type 2a spear-throwers (see Table 2 for data). Only AMS dates have been taken into account. The most likely chronological distribution for type 2a spear-throwers (ca. 19000-18000 cal BP) appears in light grey: it includes all the dates from La Garenne, Roc de Marcamps and El Mirón, as well as 4 of the 10 dates from Combe-Saunière I, and 2-3 of the 9 dates from Isturitz.

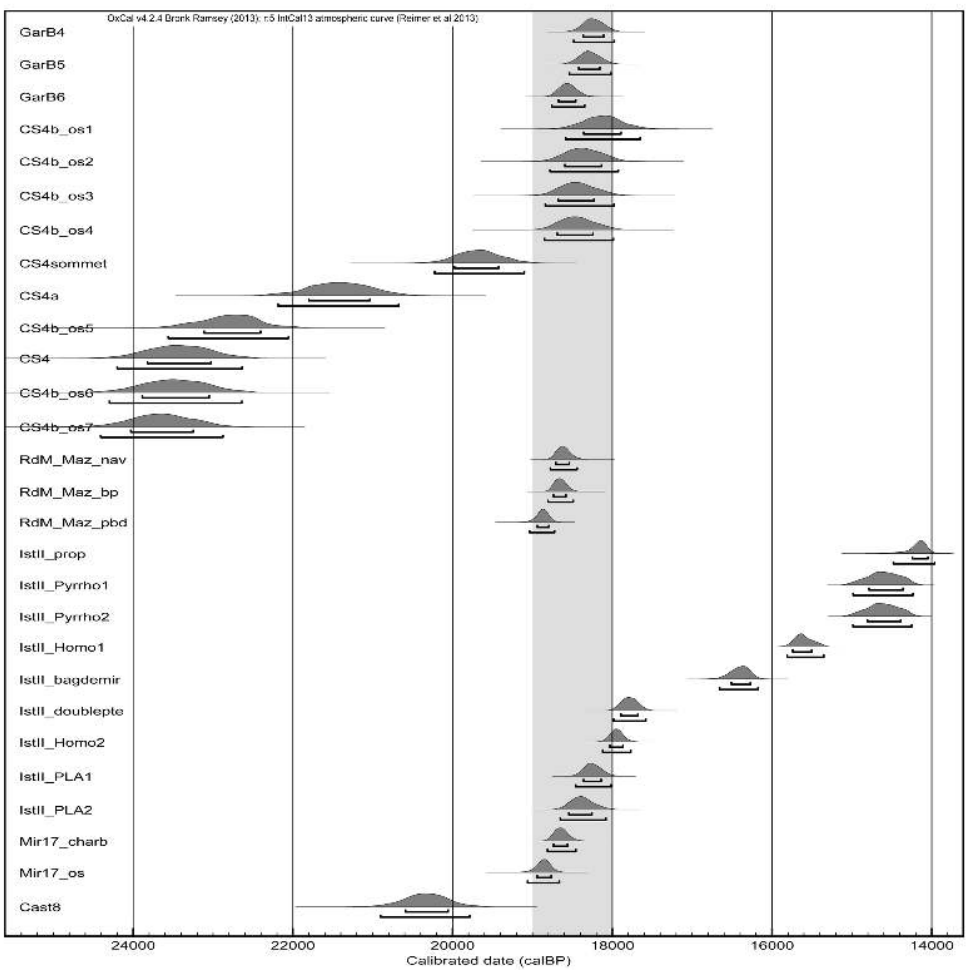


Figure 9 - Other spear-throwers from Isturitz layer II/E. 1. Type 3a spear-thrower, decorated with a horse's head, MAN 84787; 2 . Type 3d spear-thrower, decorated with a salmon, MAN 84788; Unfinished spear-thrower, MAN IST II 1931; Drawings C. Bellier 2005.
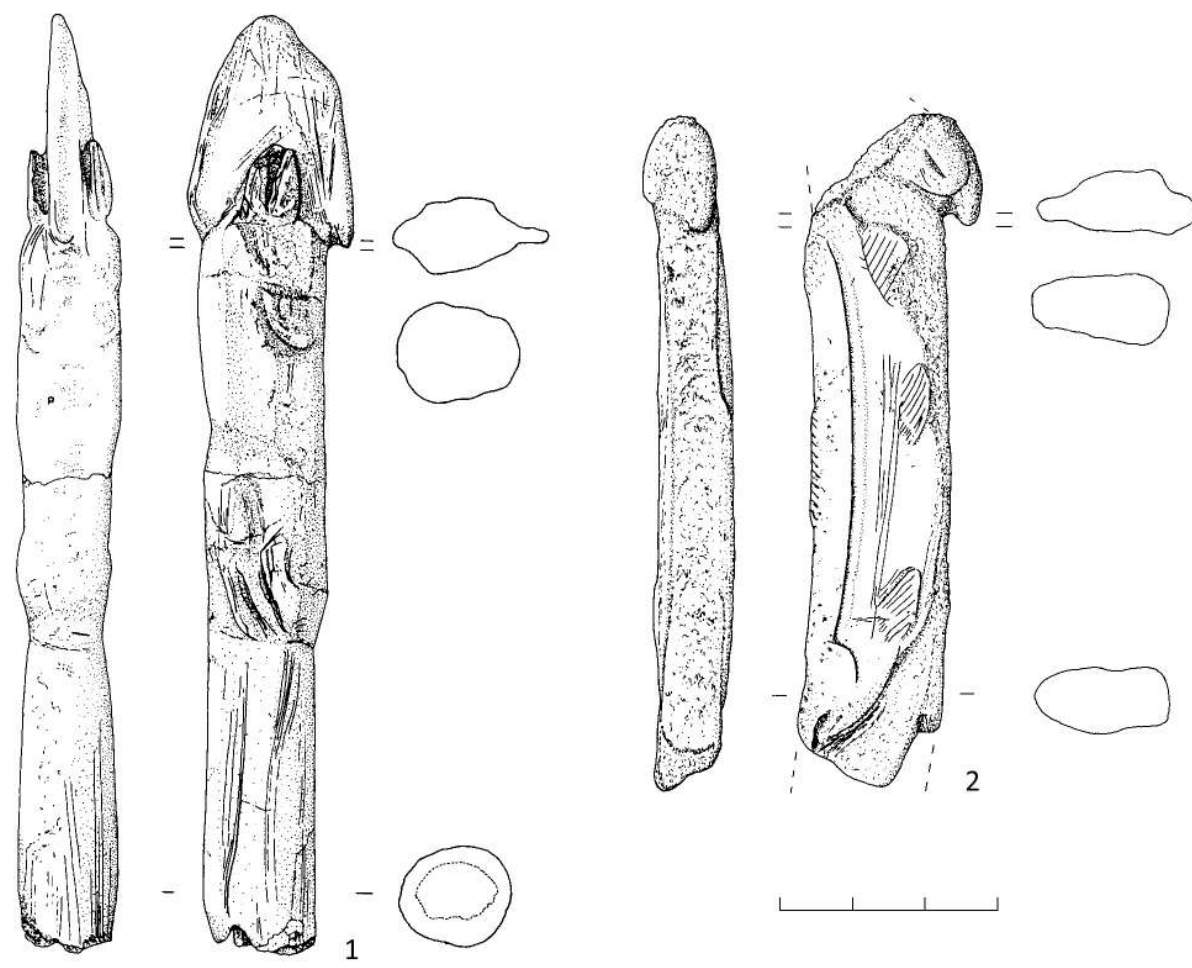

24

For the French sites, the grouping of all the "navette" facies or "Lussac-Angles points" under the designation "Early Middle Magdalenian" was proposed recently (Langlais, Pétillon, Sécher, submitted; Langlais et al. in press; Pétillon, in press; Barshay-Szmidt et al. submitted). It is beyond the scope of this paper to discuss these different appellations here. However, it seems important to point out that these attributions suggest that type 2a is earlier than the other known types of spear-thrower (types 1, 2b, 3 and 4), as the latter types are generally from contexts attributed to the "classical" Middle Magdalenian" (H. Breuil's Magdalenian IV, or "recent Middle Magdalenian" in the sense of Langlais, Pétillon, Sécher, submitted; Langlais et al. in press; Pétillon, in press; Barshay-Szmidt et al. submitted), or even to the Upper Magdalenian (Cattelain 2005).

The radiocarbon data do not contradict this hypothesis. The $14 \mathrm{C}$ dates associated with type 1, 2b, 3 and 4 spear-throwers range between 17500 and 14000 cal BP (14 300-12 300 BP: Cattelain 2005), whereas El Mirón and La Garenne spear-throwers come from levels accurately attributed to between 19000 and $18000 \mathrm{cal}$ BP, a chronological bracket consistent with the dates obtained on the bone industry from the early excavations of Roc-de-Marcamps (tab. 2 and fig. 8; however, the radiocarbon dates from the Combe-Saunière I and El Castillo spear-throwers remain problematic). 
Figure 10 - Propulseur de type 4, orné d'un cheval « assis », MAN 74904. Dessin C. Bellier 2005. Figure 10 - Type 4 spear-thrower, decorated with a "sitting" horse, MAN 74904. Drawing C. Bellier 2005.
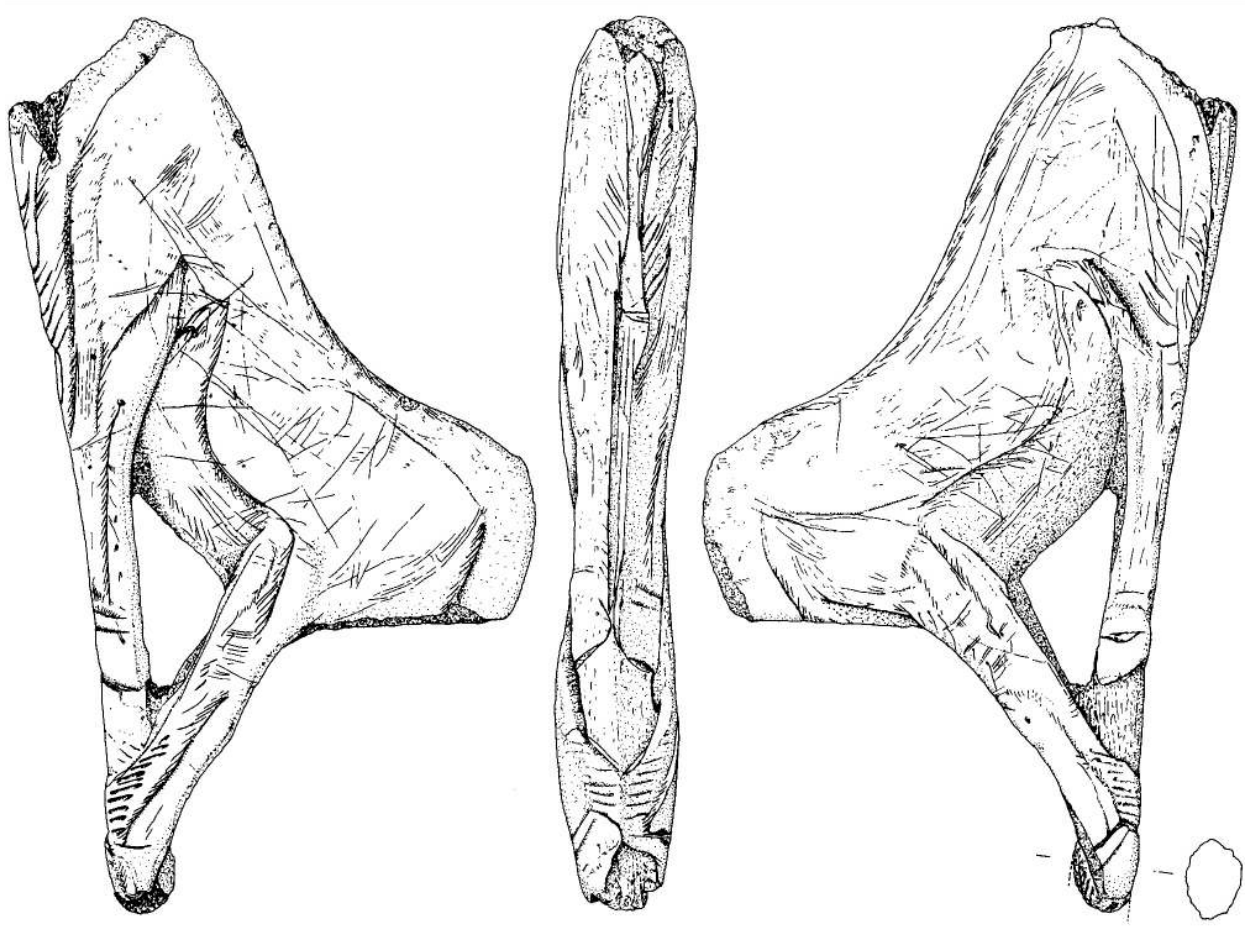

\section{The context of the Isturitz spear-thrower}

The Isturitz spear-thrower comes from layer II of the Saint-Périer excavations, corresponding to layer $\mathrm{E}$ of the Passemard excavations attributed to the Middle Magdalenian (Saint- Périer 1936; Passemard 1924, 1944; Pétillon 2004). This layer yielded a very abundant and diversified osseous industry including all the classical "markers" of the Pyrenean Middle Magdalenian (contours découpés, perforated roundels, decorated half-round baguettes...). In the lithic industry, the absence of scalene bladelets (Langlais 2010, p. 196-198) - which cannot be solely explained by selective collection during early excavations - is also a characteristic relating layer II/E to the other Middle Magdalenian complexes in the north Pyrenees (Langlais 2010 - p. 217).

Besides the type 2a spear-thrower, layer II/E also contained eight reindeer antler spear-throwers (Cattelain, in press). They include two type 3 spear-throwers (fig. 9), five type 4 spear-throwers (fig. 10), a possible spear-thrower on a perforated baton and two unfinished pieces (fig. 11). Layer II/E in the Great Hall of Isturitz thus seems to represent a unique case of stratigraphic association between a type 2a spear-thrower and almost all the other known types of spear-throwers, thereby contradicting the chronological succession hypothesis presented above. However, based on the typology of the osseous industry and on the analysis of earlier publications, one of us (Pétillon 2004, 2006) showed that this layer II/E was not exempt of intrusive pieces from the overlying Upper Magdalenian layer, and that although it was excavated as a single complex, it probably presents internal subdivisions that may correspond to the 
succession of several Middle Magdalenian facies. These observations were confirmed by a series of nine AMS $14 \mathrm{C}$ dates on osseous industry elements, human bones and faunal remains from this layer (tab. 2; Szmidt et al. 2009; Henry-Gambier, Normand, Pétillon 2013; Langlais, Pétillon, Sécher, submitted; Barshay-Szmidt et al., submitted).

Figure 11 - Unfinished spear-thrower, MAN IST II 1931. Drawing C. Bellier 2005.

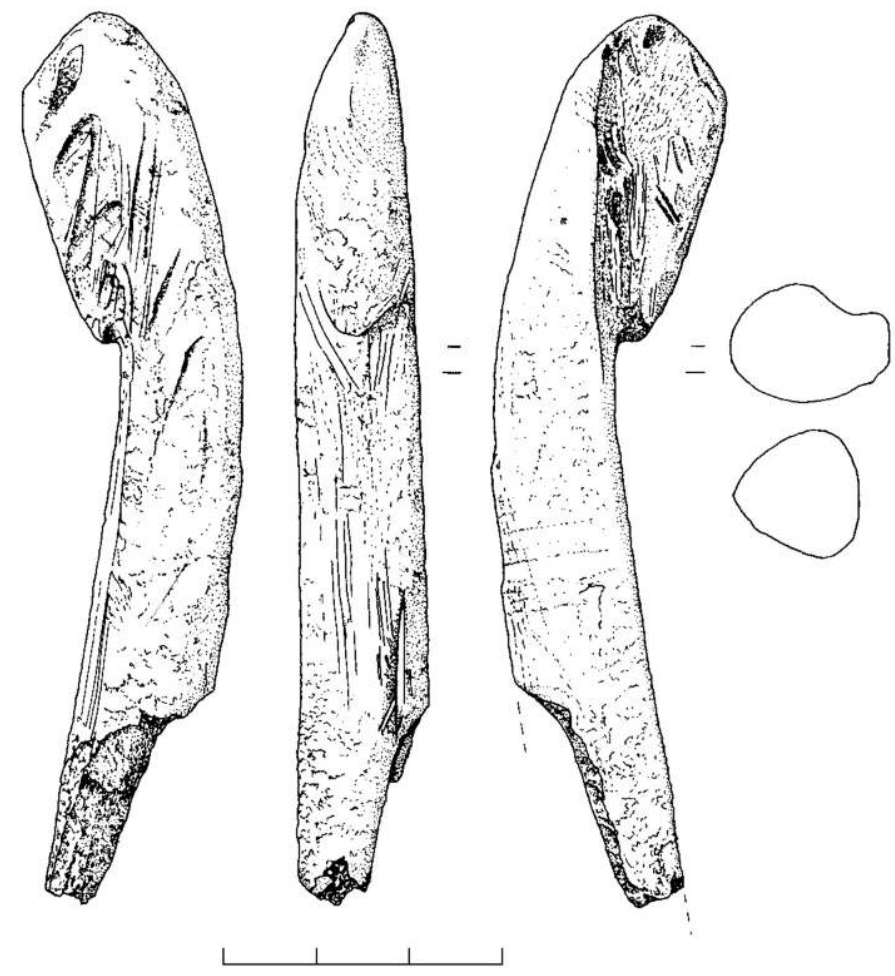

Four dates - including two on simple Lussac-Angles type bevel points, of which there are about fifty specimens in layer II/E (Pétillon 2004, 2006) - go back to the Middle Magdalenian, between about 18500 and $17500 \mathrm{cal} \mathrm{BP}$ (ca. 15 000-14 500 BP), whereas one half-round baguette with tuber decoration was dated to the end of the Middle Magdalenian (13 $605 \pm 65 \mathrm{BP}$, around $16500 \mathrm{cal} \mathrm{BP}$ ), and four other dates - on a spearthrower (fig. 11), a human remain and chough remains -, are situated between 16000 and $14000 \mathrm{cal}$ BP (ca. $13000-12000 \mathrm{BP}$ ), and thus indicate mixing with the Upper Magdalenian.

Due to the chronological heterogeneity of layer II/E, it is not possible to determine whether or not the association between the type 2a spear-thrower and the other types of spear-thrower attributed to the same level is valid. We can however observe that some of the remains from layer II/E, in particular the Lussac-Angles points, clearly belong to an early phase of the Middle Magdalenian, around $15000 \mathrm{BP}$. This date is similar to the chronological range for the other type 2a spear-throwers - in particular the object from El Mirón, the specimen from La Garenne and very probably those from Roc de Marcamps. The presence of Lussac-Angles points in Placard Cave was also emphasized by J. Allain and his collaborators (Allain et al. 1985 - p. 64). 


\section{Conclusion}

The spear-thrower rediscovered at Isturitz is part of a group of pieces that differs from the other Magdalenian spear-throwers by its typological, technological, geographic and chronological characteristics. The chronocultural attribution of these pieces remains difficult due to poorly documented discovery contexts, but also on account of the multiple terms used up until now, from Indre to the Cantabrian coast, to designate the Magdalenian facies from this period. The conjunction of several indicators shows that these type 2a objects are probably the earliest models of Palaeolithic spear-throwers. The object presented here thus contributes to reflections on the appearance and dissemination of cervid antler spear-throwers, and on the technical characteristics of these objects when they became a durable part of Palaeolithic osseous industry.

\section{BIBLIOGRAPHIE}

ALLAIN J., DESBROSSE R., KOZLOWSKI J.K., RIGAUD A. 1985 - Le Magdalénien à navettes. Gallia Préhistoire, 28 (1), p. 37-124.

ALLAIN J., RIGAUD A. 1989 - Colles et mastics au Magdalénien. In : M. Olive et Y. Taborin (Eds.), Nature et fonction des foyers préhistoriques, actes du colloque de Nemours, 1987. Nemours, APRAIF (Musée de Préhistoire d'île-de-France, mémoire 2), p. 221-223.

ALLARD M., JARRY M. 1993 - Collection R. et S. de Saint-Périer à Saint-Gaudens (Haute-Garonne). Bulletin de la Société préhistorique de l'Ariège, 48, p. 47-83.

BARANDÍARÁN I. 1988 - Datation C14 de l'art mobilier magdalénien cantabrique. Préhistoire ariégeoise, 43, p. 63-84.

BARSHAY-SZMIDT C., COSTAMAGNO S., HENRY-GAMBIER D., LAROULANDIE V., PÉTILLON J.-M., BOUDADI-MALIGNE M., KUNTZ D., LANGLAIS M., MALLYE J.-B., soumis - New extensive focused AMS ${ }^{14} \mathrm{C}$ dating of the Middle and Upper Magdalenian of the western Aquitaine/Pyrenean region of France (ca. 19-14 Ky cal BP). Proposing a new model for its chronological phases and for the timing of occupation. Quaternary International.

BREUIL H. 1937 - Les subdivisions du Paléolithique supérieur et leur signification. In : Congrès international d'anthropologie et d'archéologie préhistoriques. Compte rendu de la XIVe session, Genève, 1912. Paris, Office des éditions universitaires, p. 165-238.

CABRERA VALDÉS V. 1984 - El Yacimiento de la cueva de «El Castillo». Madrid : Instituto español de prehistoria del CSIC (bibliotheca præhistorica hispana, 22), $485 \mathrm{p}$.

CATTELAIN P. 1988 - Fiches typologiques de l'industrie osseuse préhistorique. Commission de nomenclature sur l'industrie de l'os préhistorique. Cahier II : propulseurs. Aix-en-Provence : université de Provence, $67 \mathrm{p}$.

CATTELAIN P. 1989 - Un crochet de propulseur solutréen de la grotte de Combe-Saunière I (Dordogne). Bulletin de la société préhistorique française, 86 (7), p. 213-216. 
CATTELAIN P. 2004 - Un propulseur inédit de la grotte du Placard (Vihonneur, Charente, France). Notae praehistoricae, 24, p. 61-67.

CATTELAIN P. 2005 - Propulseurs magdaléniens : marqueurs culturels régionaux ? In : V. Dujardin (Ed.), Industrie osseuse et parures du Solutréen au Magdalénien en Europe. Paris, Société préhistorique française (mémoire 39), p. 301-317.

CATTELAIN P. 2014 - Un propulseur inédit de la Grotte du Placard (Vilhonneur, Charente, France) provenant de la collection Breuil conservée à l'Institut de Paléontologie Humaine à Paris. ArchéoSitula, 34, p. 41-42.

CATTELAIN P. sous presse - Les Propulseurs d'Isturitz, Actes de la table-ronde d'Hasparren, 14 et 15 novembre 2003. Antiquités nationales, hors-série.

CATTELAIN P., STODIEK U. 1996 - Propulseurs paléolithiques inédits ou mal connus. In : J.P. Mohen (Ed.), La Vie préhistorique. Paris, Société préhistorique française / Faton, p. 76-79.

CHAUVET G. 1910 - Os, ivoires et bois de renne ouvrés de la Charente. Hypothèses paléthnographiques, Bulletin de la Société archéologique et historique de la Charente, 1, p. 1-184. DESPRIÉE J., TYMULA S., RENAULT-MISKOVSKY J. 2009 - Chronologie absolue des sites magdaléniens du coteau de « La Garenne » à Saint-Marcel (Indre). In : J. Despriée, S. Tymula et A. Rigaud A. (Ed.), Données récentes sur le Magdalénien de « la Garenne » (Saint-Marcel, Indre). La place du Magdalénien «à navettes » en Europe. Actes du colloque d'Argenton-sur-Creuse, 7-9 octobre 2004. Archéologie du Val de Creuse en Berry, $n^{\circ}$ spécial 2, Saint-Marcel, ASSAAM, p. 53-54.

GENESTE J.-M., PLISSON H. 1986 - Le Solutréen de la grotte de Combe-Saunière I (Dordogne) : première approche palethnologique. Gallia préhistoire, 29, p. 9-27.

GENESTE J.-M., PLISSON H. 1990 - Technologie fonctionnelle des pointes à cran solutréennes : l'apport des nouvelles données de la grotte de Combe Saunière (Dordogne). In : J.K. Kozlowski (Ed.), Feuilles de pierre. Les industries à pointes foliacées du Paléolithique supérieur européen. Liège, université de Liège (ERAUL, 42), p. 293-320.

GONZÁLEZ MORALES M.R., STRAUS L.G. 2009 - Extraordinary Early Magdalenian finds from El Mirón Cave, Cantabria (Spain). Antiquity, 83, p. 267-281.

HENRY-GAMBIER D., NORMAND C., PÉTILLON J.-M. 2013 - Datation radiocarbone directe et attribution culturelle des vestiges humains paléolithiques de la grotte d'Isturitz (PyrénéesAtlantiques). Bulletin de la société préhistorique française, 110 (4), p. 645-656.

KUNTZ D., SÉCHER A., COSTAMAGNO S., MALLYE J.-B., PÉTILLON J.-M., PESCHAUX C., PUBERT É., RENDU W., BOUDADI-MALIGNE M., LAROULANDIE V., BARSHAY-SZMIDT C., LANGLAIS M., 2015 Le Roc de Marcamps 2 (Prignac-et-Marcamps, Gironde) : nouvelles données sur la subsistance et les traditions techniques au début du Magdalénien moyen. Bulletin de la Société préhistorique française, 112 (3), p. 475-516.

LANGLAIS M. 2010 - Les sociétés magdaléniennes de l'isthme pyrénéen. Paris : CTHS (Documents préhistoriques 26), $337 \mathrm{p}$.

LANGLAIS M., PÉTILLON J.-M., SÉCHER A., soumis - Les débuts du Magdalénien moyen dans le Sud-Ouest français. Témoignages croisés des équipements lithiques et osseux. In : L. Chehmana, R. Malgarini, M. Po1towicz-Bobak, C. Bourdier (Ed.), L'essor du Magdalénien : faciès à navettes et à Lussac-Angles. Paris, Société préhistorique française.

LANGLAIS M., SÉCHER A., CAUX S., DELVIGNE V., GOURC L., NORMAND C., SÁNCHEZ DE LA TORRE M., sous presse - Lithic equipments as a clockwork of the internal evolution of the Magdalenian in southwest France. Quaternary International. 
LENOIR M. 1983 - Le Paléolithique des basses vallées de la Dordogne et de la Garonne. Bordeaux : université de Bordeaux I, thèse de doctorat, 2 tomes, $702 \mathrm{p}$.

LENOIR M. 1991 - Prignac-et-Marcamps, Roc de Marcamps. Gallia informations, préhistoire et histoire, 1991 (1), p. 61-62.

LENOIR M. 1993a - le Roc de Marcamps à Prignac-et-Marcamps. Bulletin de la Société linnéenne de Bordeaux, 21 (2), p. 75-85 ; 21 (3), p. 87-108 ; 21 (4), p. 131-145.

LENOIR M. 1993b - Le gisement Roc de Marcamps (Prignac-et-Marcamps, Gironde). Les Cahiers du Vitrezais, 85-86, p. 2-13.

PASSEMARD E. 1924 - Les Stations paléolithiques du Pays Basque et leurs relations avec les terrasses d'alluvions. Bayonne : Bodiou, $218 \mathrm{p}$.

PASSEMARD E. 1944 - La caverne d'Isturitz en Pays Basque. Préhistoire, 9, p. 7-95.

PÉTILLON J.-M. 2004 - Lecture critique de la stratigraphie magdalénienne de la grande salle d'Isturitz (Pyrénées-Atlantiques). Antiquités nationales, 36, p. 105-131.

PÉTILLON J.-M. 2006 - Des Magdaléniens en armes. Technologie des armatures de projectile en bois de cervidé du Magdalénien supérieur de la grotte d'Isturitz (Pyrénées-Atlantiques). Treignes: CEDARC (artefacts, 10), $302 \mathrm{p}$.

PÉTILLON J.-M., sous presse - Technological Evolution of Hunting Implements among Pleistocene Hunter-Gatherers: Osseous Projectile Points in the Middle and Late Magdalenian (19-14 ky cal BP). Quaternary International.

ROUSSOT A., FERRIER J. 1970 - Le Roc de Marcamps (Gironde). Quelques nouvelles observations. Bulletin de la société préhistorique française, 67 (1), p. 293-303.

SAINT-PÉRIER R. de 1936 - La Grotte d'Isturitz II. Le Magdalénien de la Grande Salle. Paris : Masson (archives de l'Institut de paléontologie humaine, mémoire 17), 139 p.

STODIEK U. 1992 - À propos de l'emmanchement des propulseurs au Paléolithique supérieur. In : Le peuplement magdalénien. Paléogéographie physique et humaine. Paris, CTHS, p. 317-331.

STODIEK U. 1993 - Zur Technologie der jungpaläolithischen Speerschleuder. Eine Studie auf der Basis archäologischer, ethnologischer und experimenteller Erkenntnisse. Tübingen : Archaeologia Venatoria (Tübinger Monographien zur Urgeschichte, 9), 276 p.

STRAUS L.G., GONZÁLEZ MORALES M.R. 2003 - El Mirón cave and the ${ }^{14} \mathrm{C}$ chronology of Cantabrian Spain. Radiocarbon, 45 (1), p. 41-58.

STRAUS L.G., GONZÁLEZ MORALES M.R. 2007 - Further radiocarbon dates for the Upper Paleolithic of El Mirón caves (Ramales de la Victoria, Cantabria, Spain). Radiocarbon, 49 (3), p. 1205-1214.

STRAUS L.G., GONZÁLEZ MORALES M.R., HIGHAM T., RICHARDS M., TALAMO S. 2015 Radiocarbon dating the Late Upper Paleolithic of Cantabrian Spain: El Mirón cave date list IV. Radiocarbon, 57 (1), p. 183-188.

SZMIDT C., PÉTILLON J.-M., CATTELAIN P., NORMAND C., SCHWAB C. 2009 - Premières dates radiocarbone pour le Magdalénien d'Isturitz (Pyrénées-Atlantiques). Bulletin de la société préhistorique française, 106 (3), p. 588-592. 


\section{RÉSUMÉS}

Cet article présente un propulseur en bois de renne provenant du Magdalénien moyen du site d'Isturitz (couche II, fouilles Saint-Périer de 1932 dans la Grande Salle de la grotte). Cet objet, aujourd'hui quasi complet, n'a été reconstitué que récemment (2008) à partir de deux fragments conservés dans des musées différents. Ses caractères morphométriques et techniques le rapprochent d'une série de 14 autres propulseurs provenant des sites d'El Castillo (1), d'El Mirón (1), du Roc de Marcamps (3), de Combe-Saunière I (1), du Placard (6) et de La Garenne (2). Nous proposons de dénommer ce groupe «type $2 \mathrm{a}$ ", avec cinq critères de définition: propulseur court ; généralement sur baguette, et non sur tronçon de bois de renne ; à extrémité proximale généralement en biseau simple; avec un crochet d'une forme spécifique, résultant d'un procédé de façonnage particulier; sans décor, à l'exception parfois d'incisions courtes et droites. Sur le plan typologique et technologique comme dans sa distribution géographique, le type 2a se distingue tant des autres propulseurs du type 2 que des types 1, 3 et 4 . Sur le plan chronologique, il apparaît également plus ancien et représente vraisemblablement le premier modèle de propulseur paléolithique connu. Sa datation précise reste délicate dans plusieurs sites mais, dans quelques cas (El Mirón, Le Roc de Marcamps, La Garenne), une attribution à la phase 19 000-18 000 cal BP (soit autour de 15 500-15000 BP) semble probable. Suivant les régions et les traditions de recherche, cette phase a reçu des appellations multiples: Magdalénien inférieur cantabrique, Magdalénien III, Magdalénien à navettes, Magdalénien à pointes de Lussac-Angles et, récemment, Magdalénien moyen ancien.

This paper presents a spearthrower made of reindeer antler from the Middle Magdalenian of Isturitz (Layer II, Saint-Périer's 1932 excavations in the Great Hall of the cave). This object, now almost complete, was only restored recently in 2008 when two fragments preserved in various museums were joined. Its morphometric and technical characteristics remind a group of 14 other spearthrowers from the sites of El Castillo (1), El Mirón (1), Roc de Marcamps (3), Combe Saunière I (1), Placard (6) and Garenne (2). We suggest to name this group 'Type 2a', defined by five criteria: a short spearthrower; usually made from an antler splinter, rather than from an antler's section; generally with a single-bevelled proximal end; with a hook of a specific shape, resulting from a specific shaping process; bearing no decoration, except occasionally short and straight incisions. Thus, the spearthrower of type 2 a differs from the other spearthrowers of type 2 and types 1,3 and 4 by the typological and technological aspects as well as its geographical distribution. In chronological terms, it seems to be older and may well be the first known model of spearthrower dating from the Palaeolithic. Its precise dating remains difficult for several sites, but in some cases (El Mirón, Le Roc de Marcamps, La Garenne), it probably dates back to the 19,000-18,000 cal BP phase (around 15,500-15,000 BP). Depending on the region and the research traditions, this phase has received many names: Cantabrian Lower Magdalenian, Magdalenian III, Magdalénien à navettes, Magdalenian with Lussac-Angles points, and the most recent, Early Middle Magdalenian.

\section{INDEX}

Keywords : spearthrower, Isturitz, Middle Magdalenian, Cantabrian Lower Magdalenian, Magdalénien à navettes, Magdalenian III, Early Middle Magdalenian, Lussac-Angles point

Mots-clés : propulseur, Isturitz, Magdalénien moyen, Magdalénien inférieur cantabrique, Magdalénien à navettes, Magdalénien III, Magdalénien moyen ancien, pointe de Lussac-Angles 


\section{AUTEURS}

\section{PIERRE CATTELAIN}

CReA/Patrimoine, Université libre de Bruxelles ; Musée des Antiquités Nationales, FR-78100

Saint-Germain-en-Laye ; Cedarc/Musée du Malgré-Tout, 28 rue de la Gare, BE-5670 Treignes -

pcattela@ulb.ac.be

\section{JEAN-MARC PÉTILLON}

CNRS, Laboratoire TRACES (UMR 5608), Université Toulouse le Mirail, maison de la recherche, 5 allées A. Machado, FR-31058 Toulouse cedex - petillon@univ-tlse2.fr 